\title{
An Analysis on the Implementation of Posbindu PTM Program at Beringin Raya Community Health Center Bengkulu
}

\author{
Oktarianita , Nopia Wati, Henni Febriawati dan Afriyanto \\ Public Health, Faculty of Health Sciences, Muhammadiyah Bengkulu University, Bengkulu, \\ Indonesia \\ *corresponding author, e-mail: oktarianita@umb.ac.id
}

Received: 28/09/2020; published: 30/12/2020

\begin{abstract}
Background: The implementation of Integrated Health Post or Pos Binaan Terpadu (Posbindu) Program for Non-Communicable Diseases is an effective and efficient strategy to control risk factor. The low interest in visiting Posbindu was shown from the number of visits that decreased in 2017 (75.4\%) and 2018 (64.4\%). This study aims to analyze the Integrated Health Post for Non-Communicable Diseases or Pos Binaan Terpadu Penyakit Tidak Menular (Posbindu PTM) program at Beringin Raya Community Health Center in Bengkulu. Method: This study used qualitative and descriptive approach, and was conducted in March-August 2020 using in-depth interview techniques. Results: The implementation of the Posbindu program was in accordance with the Standard Operating Procedures (SOP). Funding for this program came from the Health Operational Assistance. However, it was not sufficient. Posbindu activities were held once a month and used 5 steps system (registration, health interviews, health checks, referrals, and health education). The examination results was only recorded on the visiting book, and they did not have specific monitoring tools. The supervision of the implementation and the evaluation were discussed in the monthly mini workshop. In addition, the facilities and infrastructure were still inadequate. There was a shortage medicine supplies, and the community participation in Posbindu PTM was still low. Conclusion: Posbindu PTM has been implemented according to the SOP, but the overall implementation such as funding, drug procurement, infrastructure, and the number of Posbindu visits is still insufficient.
\end{abstract}

Keywords: analysis; implementation; Posbindu PTM program

Copyright $\odot 2013$ Universitas Ahmad Dahlan. All rights reserved.

\section{Introduction}

Non-Communicable Diseases (NCD) account for almost $70 \%$ deaths in the world. NCDs refer to chronic diseases including heart disease, stroke, cancer, diabetes, and chronic obstructive pulmonary disease (COPD). There has been an increasing trend of NCDs recently. According to the results of the Basic Health Research or Riset Kesehatan Dasar (Riskesdas) in 2007, 2013, and 2018, there was an increasing trend in the prevalence of NCDs [1]. Deaths attributed to NCDs in Indonesia according to WHO data (2014) consisted of cardiovascular disease $(37 \%)$, cancer $(13 \%)$, chronic lung disease $(5 \%)$, diabetes (6\%), and other NCDs (10\%) [2].

The preliminary analysis of 2018 Sample Registration Survey (SRS) showed a similar pattern. Rationally, the top ten causes of death were NCDs, namely cerebral vascular disease $(19.9 \%)$, ischemic heart disease (13.3\%), diabetes mellitus $(7.9 \%)$, hypertension with its complications $(5.8 \%)$, chronic lower respiratory tract disease $(5.1 \%)$, and traffic accidents $(2.6 \%)$. The high mortality rate due to Non-Communicable Diseases (NCDs) means that it is crucial to control the risk factors associated with these diseases. Early detection and appropriate treatment are important in controlling NCD [3].

Integrated Health Post for Non-Communicable Diseases or Pos Binaan Terpadu Penyakit Tidak Menular (Posbindu PTM) is an effective and efficient NCDs control strategy that aims to provide a preventive measure for early detection of NCDs risk factors in the 
community so that they can get appropriate treatment [4]. The Integrated Health Post or Pos Binaan Terpadu (Posbindu) are activities from, by, and for the community. The main activities are held regularly and periodically in an integrated way. The targets of Posbindu PTM are groups of people who are healthy, at risk of NCDs, and people with NCDs aged $\geq$ 15 years old [5].

Posbindu PTM is implemented using a 5-table system, namely registration, measurements, filling out the Health Card or Kartu Menuju Sehat (KMS) and NCDs Risk Factor Card or Faktor Resiko PTM (FRPTM), and health services. There are 10 Posbindu PTM activities, namely collecting information on NCDs risk factors through simple interviews, measurement (body weight, height, BMI, waist-hip ratio, analysis of body fat and blood pressure), simple lung function test, blood sugar test, total cholesterol and triglycerides test, visual inspection of acetic acid or Inspeksi Visual Asam Asetat (IVA), examination of respiratory alcohol levels and ampheminurin tests, counseling, physical activities and / or joint sports, and referral to basic health care facilities [6].

Beringin Raya Community Health Center has 8 Posbindu PTM, namely Posbindu Mawar I, Mawar II, Medan Baru (Kandang Limun), Teratai V and Teratai VI (Rawa Makmur), Sungai Hitam and Anggrek (Beringin Raya) [7]. According to the records of Beringin Raya Community Health Center, the total number of participants who took part in Posbindu PTM activities from 8 Posbindu in the last 3 months of 2019 were 140 people in October, 72 people in November, and 130 people in December [7]. This showed that there was still a very low participation from healthy group, at risk groups, and people with NCD aged $\geq 15$ years old. The participants of Posbindu PTM in the working area of Beringin Raya Community Health Center Bengkulu City was dominated by adults and the elderly. The achievement indicator of patients completing the basic and primary Posbindu PTM was was also found to be still in the low category, namely $<50 \%$ of $20.2 \%$. The percentage of villages implementing Posbindu PTM has not reached $100 \%$. Therefore, it is important to pay attention to the implementation of Posbindu program at Beringin Raya Community Health Center, Bengkulu City. Based on this background, this study aims to analyze the implementation of Posbindu PTM at Beringin Raya Community Health Center, Bengkulu City.

\section{Method}

This study follows a qualitative research design with a descriptive approach. Data were collected by using in-depth interviews with key informants and triangulation. There were 5 informants (informant 1: Head of Community Health Center, informants 2: person in charge of the Posbindu PTM program, and informants 3, 4 and 5: nurses) and 8 Triangulations (Triangulation 1, 2, 3: volunteers and Triangulation 4, 5, 6, 7 and 8: Posbindu PTM participants). Instruments to collect the data were interview guidelines, observation, and documentation of Posbindu PTM program activities. This research focuses on the implementation of Posbindu PTM program at Beringin Raya Community Health Center, Bengkulu City including human resources, facilities and infrastructure, funding sources, application of the 5 table system, referral system, outreach program, recording and reporting, as well as monitoring and evaluation of the program. Data processing with data reduction in the form of a narrative description are presented descriptively.

\section{Results and Discussion}

\subsection{Results}

\subsubsection{Human Resources of Posbindu PTM Program}

Based on the results of in-depth interviews with informants, Posbindu Program was run by 2 health workers and 3 volunteers. It was in accordance with the statement as follows:

"for each Posbindu, 2 health workers and 3 volunteers" (Informant 1).

"the officers are health workers and volunteers, so in every Posbindu there are 5 officers" (Informant 2). 


\subsubsection{Training of Health Officers}

The results of the study showed that the training for the officers related to Posbindu had been conducted, but the training was only attended by the person in charge of the Posbindu PTM program while other officers received general training. Meanwhile, the training for volunteers was limited to measurements and recording. This is in accordance with the statement Informant 1, as follows:

"Training for volunteers has been carried out just recently, then the new training for person in charge will be given by Balpelkes officers, the certificate should have been available, but it is not given yet" (Informant 1).

\subsubsection{Facilities and Infrastructure of Posbindu PTM Program}

The results of interview regarding the facilities and infrastructure of Posbindu PTM program at Beringin Raya Community Health Center showed that Posbindu is usually held at residents' houses, volunteers' houses, and meeting centers. This, the infrastructure of Posbindu program at Beringin Raya Community Health Center is still inadequate. This is in accordance with the statement of the research informants as follows:

"Because the activities are held outside the Community Health Center, it is held in the volunteers' house or residents' houses and the facilities and infrastructure from the Community Health Center are sufficient, everything needed is available" (Informant 1).

"The program is held in the residents' or volunteers' houses. It is still inadequate, and there are no infrastructure and facilities. There are some tools unavailable such as body fat analysis monitor" (Informant 2).

"The tools from the Community Health Center such as measuring instruments for waist-hip ratio, weight, and blood pressure are available, but the equipment for body fat analysis is not available yet. The place for the program is usually at the volunteers' house or at the meeting hall, but it is not sufficient" (Informant 5).

\subsubsection{Posbindu PTM Program Fund Sources}

Based on the results of in-depth interviews with informants, it was revealed that the operational costs for implementing the Posbindu program comes from Health Operational Assistance or Bantuan Operasional Kesehatan (BOK) funds, but these funds were only for the officers' travel expenses while the funds for volunteers' travel expenses were not available yet. The infrastructure or procurement of equipment for Posbindu program comes from the Health Office. This is in accordance with the statement of the informants, as follows:

"These funds come from health operational assistance (BOK) funds, however, these are only for officers' travel expenses while the funds for volunteers are not available yet. Therefore, only volunteers who have a strong will to participate and are capable were selected, and from beforehand they have been told if there are not funds for them yet" (Informant 2).

The statement above was supported by the following statement from the Informant 1 :

"For Posbindu activities, there are funds from the Central Office for health operational assistance funds. If it is not enough, what's available is used for travel expenses. In terms of procurement, the equipment is from the Community Health Center and the Health Office" (Informant 1).

The Informant 3 also mentioned that:

"Funds for the Posbindu Program come from health operational assistance funds. 
Usually, the funds are for travel expenses. The equipment is from the Health Office. Other funds are not yet available" (Informant 3).

In accordance with volunteers' statement that there is no travel expenses fund for volunteers and the reason why volunteers still want to participate in the Posbindu Program activities even though there is no funding, was known from the results of interview, as follows:

"Yes, there is no funding yet. Previously, this matter has been explained by the Community Health Center itself. So, those chosen were volunteers who wanted to help the program. Other volunteers are also willing to help. Well, I don't mind about that. As long as it's for goodness' sake, we still can help" (Triangulation 2).

\subsubsection{The Implementation of Posbindu PTM program on a 5 table system Table 1 (Registration)}

The first step to do is registration. Participants coming to Posbindu PTM fill the registration book provided by the Posbindu management. This is in accordance with informants' statement, as follows:

"First, participant must fill in the identification form" (Informant 2).

"First, participants register themselves, fill in their personal identities, then we will collect their data" (Informant 3).

This statement is also supported by the statement of a triangulation source, as follows:

"When I arrived, I was asked to write my identity and age at registration by the officer. Usually, the volunteers write it down" (Triangulation 5).

Table 2 (Interview about health issues)

The results of the study regarding interviewing health issues in Posbindu showed that the interviews were carried out by the working nurses and volunteers. This is in accordance with the informant statement, as follows:

"Yes, interviews are conducted. The implementation is based on 5 table system. Table 1 is registration. Then, Table 2 is for health issues interviews such as complaints. It's us who usually do it, but sometimes volunteers are also in charge" (Informant 2).

The statement above is supported by the following statement from the Informant 1:

"Obviously, interviews are conducted. Usually, after registration, an interview is conducted regarding health issues. The nurse do the interview" (Informant 1).

This is also in accordance with the following statement of a triangulation source that an interview on health issues is conducted:

"Yes, sure. We are asked; whether we have health issues or not. The point is that as soon as you come, you write your name, age, and usually there are a lot of questions asked about health issue" (Triangulation 4).

\section{Table 3 (Measurement and Health Examination Activity)}

The health measurement and examination activity at Posbindu PTM at Beringin Raya Community Health Center consists of measurements of body weight, height, and waisthip ratio. This is in accordance with the Informant 2 statement, as follows: 
"Measurements consists of body weight and height. This is done at table 3 by a volunteer and one of Community Health Center officers. In the case of examination, there is usually a one-packet examination consisting of blood sugar test, cholesterol test, and uric acid test which is conducted every month in every Posbindu activity" (Informant 2).

Likewise, the Informant 1 stated that:

"Measurement activities carried out include measuring weight and height. For examination, there are test for blood pressure, blood sugar, uric acid, and cholesterol" (Informant 1).

The statement above is supported by the following statements of a triangulation source:

"There are measurement activities, and we record the data. The height has been measured, the waist-hip ratio is like this. The examination activities consist of blood pressure test, blood sugar test, uric acid test, and cholesterol test. Visitors can take a complete package if they want. A complete package costs IDR 50 thousand. They can also choose to do the measurement one by one depending on the health officer, the officer from Community Health Center. It is usually held every month" (Triangulation 2).

\section{Table 4 (Referral Activities and Other Follow Up Activities)}

Based on the results of interviews, referral activities and other follow-up activities for Posbindu participants with NCDs have been conducted. Some sick participants were urged to come to the Community Health Center so they could receive treatment because Posbindu itself does not provide health services. Meanwhile, the referral system for Posbindu participants was only in the form of recommendations for treatment at Community Health Center. If a NCD case can no longer be handled at Beringin Raya Community Health Center, a referral to other hospital is made. The referral system for Posbindu PTM participants was in the form of recommendations for treatment at the health center by carrying a Badan Penyelenggara Jaminan Sosial (BPJS) card. This is in accordance with the following statement of Informant 3:

"So far, there are several high blood pressure patients who also have health issues. We recommend them to go to the Community Health Center for treatment. The system also gives the same advice, go to the Community Health Center and bring a BPJS card. It all depends on the participant, but usually if a participant is sick they come directly to the Community Health Center" (Informant 3 ).

The statement above is in line with the following statement of Informant 2:

"Yes, that reference. If there is a disease that must be referred to, we definitely refer it to the Community Health Center immediately. Sometime ago, there were many hypertension cases, so they came directly to Community Health Center for further treatment" (Informant 2).

The following is the statement of the Informant 1 regarding the implementation of referrals at Posbindu PTM:

"If a disease is detected, the officer explains it to them and immediately referred them to Community Health Center" (Informant 1).

The same statement is also supported by a triangulation source, as follows:

"If there are participants who, for example, have high blood pressure, or high sugar levels, they will be sent to Community Health Center for treatment together with the 
staff by carrying a health card. Usually, they are told to take medicine" (Triangulation 1).

\section{Table 5 (Recording and Reporting)}

The results of the interviews showed that recording and reporting have been conducted by the Community Health Center every month and at the end of the year. However, the results of examinations were still recorded on the record book provided by the Community Health Center. This is in accordance with the Informant 2 statement, as follows:

"recording and reporting is conducted every month. There are monthly and annual reports. Well, there are visit reports, and all reports related to Posbindu activities" (Informant 2).

Likewise, the Informant 1 mentioned that:

"The visit to Posbindu are recorded, and a report is made every month and at the end of the year. There are monthly and annual reports" (Informant 1).

The statement above is supported by the following statement of the Informant 4:

"The record is written in every Posbindu visit" (Informant 4).

\subsubsection{Promotion and Outreach of Posbindu PTM Program}

The results of the interviews showed that promotion and outreach of Posbindu PTM program has been conducted both by the Health Office and the Beringin Raya Community Health Center to the community. Yet, these have not been carried out officially because it was only delivered during Posbindu activities such as promotions by the working nurse and the person in charge of program during Posbindu every month. Moreover, there has been no direct counseling in collaboration with Health Promotion party related to the Posbindu PTM program. Posbindu was held at village head office or the meeting hall of Beringin Raya Community Health Center. This is in accordance with the Informant 4 statements, as follows:

"Promotion and outreach to the community are usually delivered during Posbindu activities every month. However, there has been no health campaign in direct collaboration with Health Promotion as it is only limited to neighborhood, village, and volunteers" (Informant 4).

This statement is in line with that of Triangulation 1, as follows:

"Sometime ago, there was a promotion. When Posbindu is held, promotion is also delivered. Officers from the Community Health Center convey it every month during Posbindu, but only in brief. At least, the promotion and outreach encourage the community to be more active in Posbindu participation" (Triangulation 1).

The statement above is supported by the following statement of Informant 2:

"There are people from the community. Usually, it is held at the village head's office or other meeting places, but it is not an official event. Still a part of other activities, and usually in collaboration with the village head and the head of neighborhood. Promotion and outreach encourages the public to be more active in Posbindu". (Informant 2).

\subsubsection{Recording and Reporting of Posbindu PTM Program}

The results of the interviews revealed that recording and reporting has been conducted by Beringin Raya Community Health Center. Recording was conducted in 
each Posbindu program, but was still written on the record book. There was no Health Card (KMS) yet. A report on the implementation of Posbindu was written every month and at the end of the year to the City Health Office Bengkulu.

The Bengkulu City Health Office received reports from the Community Health Center regarding the implementation of Posbindu PTM including visit reports every month. This is in accordance with informants' statement, as follows:

"There is no health card yet" (Informant 1).

"The examination results are only written on the record book during Posbindu. The Health Card (KMS) for participants is not available yet. Although already submitted, it has not been approved until now. Meanwhile, the post implementation report is evaluated in every meeting" (Informant 2).

The same statement is also mentioned by the triangulation sources, as follows:

"The results of examination are still recorded on the notebook. Health Card (KMS) is not available yet" (Triangulation 1).

"There is no Health Card (KMS) yet" (Triangulation 5).

\subsubsection{Monitoring and Evaluation of Posbindu PTM Program}

According to the result of the interviews, monitoring and evaluation of Posbindu program have run well because they were held every year. Monitoring and evaluation was conducted at the Bengkulu City Health Office every year. If there is a problem, it will be discussed and followed up. This is in accordance with informants' statement, as follows:

"Yes, program monitoring is conducted. Evaluation is carried out annually. The evaluation is done by reviewing the monthly and annual reports to see whether the program has met the standards of the Health Office or not" (Informant 1).

"In terms of evaluation, there is usually a monitoring and evaluation activity conducted directly by the Health Office sometimes. Well, it is not certain" (Informant 2).

"There is monitoring, but not regularly conducted. The program is evaluated in a mini-workshop" (Informant 3).

\subsubsection{The Obstacles of Posbindu PTM Implementation}

The results of the interview showed that the obstacles of Posbindu PTM program included internal obstacle, namely lack of medicine supplies, and the operating hours of Posbindu which was the same as the community working hours. Thus, people are less interested in coming to Posbindu because they prioritize work. As a result, not all age groups come to Posbindu. This is in line with the statement of informant and triangulation source, as follows:

"Most of the internal funds are for travel expenses, so funds for volunteers are not available yet. The community is not really eager or less interested in visiting Posbindu. Sometimes, the equipment is limited so the strategy is to provide a complete package (check blood sugar, uric acid and cholesterol) for participants that costs IDR 50 thousand" (Informant 3).

This statement is in line with that of Informant 2, as follows:

"There are internal and external obstacles. The latter mostly involves the lack of participation from the community. Their interest is low even though they have been told to come. They are not interested because they start their activities from early 
morning so maybe they are busy. That's why most people who come here are mothers and elderly people. Besides that, the medicine supply is not sufficient, and funds are still limited. There are some tools that are not available yet" (Informant 2).

This is line with the following statement from the Informant 1:

"The obstacle is the low awareness of healthy living and lack of interest in Posbindu participation" (Informant 1).

The following statements from the triangulation of sources indicate the same thing:

"When invited to Posbindu, most people are afraid of seeking treatment or afraid of finding out that they have diseases. They lack of health monitoring awareness, and are afraid of health examination. They are demotivated because they cannot get the necessary medicine every time they have a health examination" (Triangulation 1).

\subsection{Discussion}

\subsubsection{Human Resources of Posbindu PTM Program}

Posbindu is held by the working nurses and volunteers trained by health workers who are willing to organize Posbindu PTM. They have been specially trained and facilitated to monitor NCDs risk factors in their respective groups or organizations. The criteria for Posbindu volunteers include minimum high school education, and willingness as well as the ability to carry out activities related to Posbindu PTM [6].

According to the results of study at Beringin Raya Community Health Center, there were 2 health workers Posbindu including nurses. Each Posbindu in Beringin Raya Community Health Center work area had 3 volunteers. Ideally, there should be 5 Posbindu officers who have their respective duties and divisions, namely as volunteer coordinator, volunteer manager, volunteer supervisor, promotion volunteer, and administrative volunteer [6]. Therefore, the personnel of Posbindu PTM at Beringin Raya Community Health Center is already sufficient.

Community Health Center has responsibilities and duties in health development that has a region-oriented concept. The implementation is based on the principle of integrating all available resources such as cross-sectoral, stakeholder, community groups, families and individuals in the Community Health Center. The Community Health Center coordination with related sectors improves public health and develops healthy families by increasing community participation in Posyandu and Posbindu PTM [8].

\subsubsection{Training of Posbindu Officers}

This study found that the training for health officers of Posbindu PTM has been carried out albeit not specifically. Only the person in charge of the program has attended the training. In addition, the volunteers only received training and general materials about Posbindu PTM. Training for volunteers was only in the form of direction regarding the technical implementation of the program. Formal training for volunteers has not been conducted so the performance of volunteers in Posbindu PTM at Beringin Raya Community Health Center is still low.

The obstacle in the training for the nurses and volunteers is the absence of special training related to Posbindu program. Volunteers as workers need to receive special training so they can carry out their roles and duties well. That way, volunteers can encourage and influence people to be willing and be able to participate in Posbindu program. Thus, it can increase the target of community visit. The purpose of training for health officers is to educate people about the risk factors, impacts, and control of NCDs, to give information about Posbindu PTM, and develop the abilities and skills in monitoring risk factors [9].

\subsubsection{Facilities and Infrastructure of Posbindu PTM Program}

According to the results of the study, the existing facilities and infrastructure in the implementation of Posbindu were inadequate such as the unavailability of body fat and 
triglycerides monitor, shortage of drug supply, and the absence NCD Risk Factors Monitoring Card or FR-PTM. Moreover, there was no specific meeting places for Posbindu participants. The minimum standard facilities for Posbindu PTM consists of equipment such as height measuring instruments, weight scales, waist-hip ratio measuring tape, blood pressure monitor, measuring instruments for body fat analysis, and educational props. Then, the complete standard facilities include blood sugar monitor, total cholesterol and triglyceride monitor, blood alcohol calculator, urine amphetamine test kits, and IVA kits [6]. So far, the facilities and infrastructure used in the Posbindu PTM activities are scales, height measurement tools, waist-hip ratio measuring instruments, blood pressure monitor, cholesterol test kits, blood sugar monitor, KMS FR-PTM, and notebook for recording and reporting activities [10].

\subsubsection{Posbindu PTM Program Fund Sources}

The results of the study showed that the source of operational costs in implementing Posbindu PTM program came from BOK funds. Operational costs were in the form of officers' travel expenses. Meanwhile, the travel expenses for volunteers were not available yet. In order for Posbindu PTM to run well, Posbindu activities need other funds such as compensation for volunteers' travel expenses, funds for procurement of consumable, and funds for purchasing additional supplies. This is in line with the result of previous study where it reported that the source of Posbindu funds came from Regional Revenue and Expenditure Budget or Anggaran Pendapatan dan Belanja Daerah (APBD), State Budget or Anggaran Pendapatan dan Belanja Negara (APBN), and health operational assistance funds [11].

According to the Indonesia Ministry of Health in 2012, adequate financing is needed to support the implementation of Posbindu PTM, both from independent funds such as from companies, community groups / institutions as well as support from other parties. Funds that can be used to support Posbindu activities include operational costs, reimbursement of volunteers' travel expenses, procurement of consumables, costs of purchasing Complementary Foods, costs of organizing meetings, and referral costs for those in need [6].

In line with previous research, sufficient financial resource is important in supporting the implementation of Posbindu; whether it is in the form of independent resources, community groups/institutions, or the support of other parties who care about NCDs issues in their respective work areas. Community Health Center can also take advantage of potential financial sources to support and facilitate Posbindu PTM, one of which is through the local government which is obliged to provide a training so that Posbindu PTM continues to grow and develop through policy support including sustainable financing. Funds collected from various sources can be used to support Posbindu PTM activities such as operational costs, reimbursement of volunteers' travel expenses, costs of consumables procurement, costs of purchasing additional food supply or Pemberian Makanan Tambahan (PMT), costs of organising meetings, assistance for referrals, and grief expenses assistance if a member has an accident or passed away [12].

\subsubsection{The Implementation of Posbindu PTM Program}

The result of the study revealed that the implementation of Posbindu has met the SOP of Community Health Center. The program was held regularly according to the agenda or schedule that was on the second week of every month. The operating hours was from 09.00 WIB to 12.00 WIB. Posbindu PTM at Beringin Raya Community Health Center was held at the Village Head Office, Meeting Hall, or villagers' house. The role of volunteers is very important in the implementation of Posbindu PTM activities since the day before, on the opening day, and after the opening day of Posbindu PTM.

Before the opening day of Posbindu, volunteers must prepare the program such as preparing tools and materials and inviting residents to come to Posbindu. On the day of the opening, the duties of volunteers are to open a 5 table system service (registration, health interviews, health checks, health referrals, and counseling) and after the opening day of the Posbindu PTM, volunteers must evaluate the results of the activities and plan the Posbindu activities for the following month. The activities uses a 5 table system and is carried out sequentially according to the procedures that have been prepared, and all the results of Posbindu activities are recorded by volunteers and then submitted to the Community Health Center for evaluation. This result is in line with previous research 
regarding the implementation of Posbindu PTM at Simpang Sungai Duren Public Health Center that used a 5 table system. Yet, there were still several obstacles, one of which was the role of volunteers was not up to the expectation [13].

The finding of this study also showed that referrals and other actions at table 4 has been carried out systematically. Referral for Posbindu PTM participants has been conducted. Some participants who had health issue were urged to come to Community Health Center in order to receive treatment because Posbindu PTM itself did not provide health services. Meanwhile, the Posbindu PTM referral system only took the form of a recommendation to go to Community Health Center with a BPJS card. The results of interviews with the Head of the Community Health Center and the working nurses revealed that if a case can no longer be handled at Beringin Raya Community Health Center, a referral will be made to other hospital such as city hospital, Bhayangkara Hospital, M. Yunus Hospital, and other hospitals.

The Posbindu referral system supports comprehensive health services for the community to the highest level of service. The benefit of Posbindu PTM is as a community-based health effort where targets and empowered communities must play an active role in health activities and programs for the implementation of Posbindu PTM starting from registration and being registered, being a member, and finishing the activities. This helps Community Health Center to detect NCDs such as diabetes mellitus (DM), high blood pressure, cancer, and other diseases. Followed by treatment, it can prevent and control diseases, and also reduce pain levels [8].

\subsubsection{Recording and Reporting of Posbindu PTM Program}

The result of the study revealed that recording and reporting has been conducted by Beringin Raya Community Health Center. Recording was conducted at every Posbindu program, but participants have not had a Health Cards (KMS) as a health monitoring tool during the examination yet. This is in line with the results of previous research which stated that Posbindu activities in Bogor were routinely held once a month [14]. However, the implementation was not fully in accordance with the 2012 Posbindu PTM Technical Guidelines from Ministry of Health. We found that several activities or steps were not conducted. For example, in the first stage, not all results in the KMS FR-PTM were written on the notebook. The volunteers wrote down the names and ages of the participants then the participants were measured. However, not all examination results were in accordance with the written guidelines on the health card notebook. Only height, weight, blood pressure, blood sugar, and cholesterol levels were recorded. The cards owned by the participants also did not have a monitoring sheet, so the monthly progress of the participants was not immediately known.

Meanwhile, the reporting of the implementation of Posbindu was submitted every month and at the end of the year to the Health Office. The Bengkulu City Health Office received reports from the Community Health Center regarding the implementation of Posbindu PTM every month including visit reports. In the monitoring, the parties being examined and the examiner must know the condition of NCD risk factors. Each participant is required to have an individual monitoring tool in the form of FR-PTM as a health monitoring tool during the examination. This card is kept by every participant, and must always be taken when visiting Posbindu events. The goal is that every individual can take action and provide follow-up suggestions according to the conditions of Posbindu participants [6].

\subsubsection{Promotion and Outreach of Posbindu PTM Program}

The finding of the study showed that the promotion of Posbindu PTM involved the coordination with village head and volunteers and was delivered in every Posbindu program. The program was promoted when providing health services or Posbindu. However, in reality, the promotion was briefly given, and the types of services provided by Posbindu PTM were not informed. Promotion should be carried out directly in collaboration with the Health Promotion and conducted regularly every month especially in Posbindu PTM program so that the community know about the program [9].

It is necessary for the community to be informed regarding health issue. Information will be fully received when a person or group are continuously exposed to information. The result of the research revealed that partnership is important in implementing 
Posbindu PTM, especially in improving funds, personnel, and infrastructure for the development of activities. The success of Posbindu PTM is largely determined by the involvement and active role of various parties ranging from the government, community organizations, professional organizations, private sector, and others [15].

\subsubsection{Monitoring and Evaluation of Posbindu PTM Program}

The result of the research revealed that the monitoring and evaluation of Posbindu PTM program had been carried out. The supervision was conducted during Posbindu while program evaluation was conducted every year along with other programs. This evaluation was conducted by looking at the monthly reports of each program that have been recapitulated into an annual report and see whether there were any problems. The annual report for each program was adjusted to the achievement of program targets based on the standards from the Health Office. Programs that did not reach the target would be analysed and solutions would be provided to program directors.

In line with the previous research, the success of a Posbindu program is strongly influenced by monitoring and evaluation conducted by the leadership. Therefore, monitoring and evaluation must be conducted at Community Health Center level or the level of health services related to the implementation of Posbindu [11]. Another research reported similar result. The monitoring and evaluation of Healthy Indonesian Program with a Family Approach or Program Indonesia Sehat dengan Pendekatan Keluarga (PIS-PK) at the Jalan Gedang Community Health Center was conducted by reviewing the results of data collection. After the results were obtained, Family Health Index or Indeks Keluarga Sehat (IKS) was classified. If the IKS was found to be under the minimum criteria, a repeated visit to several families with low IKS was conducted in 2019 as an intervention attempt so that the results of IKS improved [16].

Supervision and assessment were carried out regularly at monthly mini-workshops. If the target has not been reached by the specified time, the Community Health Center would make special actions and do a re-planning which would be discussed in the monthly mini-workshop involving officials and related stakeholders [17].

\subsubsection{The Obstacles in the Implementation of Posbindu PTM Activities}

The study has found that the number of Posbindu visits was still low. Participants consisted of a small group of people who were healthy, at risk, and those with NCD. These were dominated by adults and the elderly who took advantage of Posbindu PTM. People were busy working. Thus, it is necessary to make a coordination about the time of the program in order to overcome the lack of Posbindu visits.

Previous studies reported that the number of participants was still low even though the program was held more than once a month because many people work on that day and time [13]. Another research also found that Posbindu PTM participants were dominated by the elderly because volunteers were inactive in conveying information to the targets of Posbindu PTM program. Moreover, the volunteers have taken no steps to encourage community's participation. In addition, there has been no data collection or information outreach done in these areas. As a result, no teenager participated in the implementation of Posbindu PTM program [18].

The role of volunteers is to arrange and make the schedules in coordination with the village head to get precise and accurate information so that Posbindu PTM can be held at the right time where the community is not busy working or doing daily activities as well as activities in Community Health Center. Posbindu officers should make a coordination with Community Health Center officers to determine the schedule and reduce the risk of schedule clash. The accuracy of determining the schedule for the implementation of Posbindu PTM has an impact on the attendance of Posbindu participants [13].

Previous study revealed that support from health workers through Posbindu PTM facilitation such as body fat analysis monitor, digital blood pressure monitor, and especially free blood laboratory tests (blood sugar, total cholesterol, triglycerides, and sometimes uric acid) also encourages the surrounding community to be enthusiastic about attending Posbindu PTM activities [19]. The implementation of Posbindu PTM is very important. Therefore, it requires the support and active role of health workers, family members and community leaders to motivate each other in order to raise community's awareness to take advantage of Posbindu PTM and maintain community health [20]. 


\section{Conclusion}

Posbindu PTM program was implemented based on the Standard Operating Procedures (SOP) of Community Health Center and conducted by health workers and Posbindu volunteers. The budget came from the Health Operational Assistance (BOK) fund, but it was not sufficient for the overall implementation of Posbindu activities. Posbindu was conducted according to the schedule (on the second week of every month) and used a 5 table system, namely: registration, interview, measurement of height and weight, waist-hip ratio, blood sugar test, uric acid test, and cholesterol test. The results of health examination were recorded in a book provided by the Community Health Center. In addition, participants attending Posbindu PTM have not had Health Card (KMS) as a health monitoring tool. Then, the implementation of Posbindu was reported every month and at the end of the year. Supervision was conducted during the implementation of Posbindu, and evaluation of activities was discussed in mini-workshops every month and at the end of year. There has not been any cross-sector cooperation with the health promotion party yet. Facilities and infrastructure were still inadequate, and there was a lack of medical supplies. The funds for Posbindu activities were insufficient, and the participation of the risk groups and the whole community was low. Moreover, it was only dominated by adults and the elderly who took advantage of Posbindu health service.

\section{References}

1. Kementerian Kesehatan RI. Laporan Nasional Riskesdas 2018. Kementeri Kesehat RI Badan Penelit dan Pengemb Kesehatan Jakarta.

2. Kemenkes RI. Rencana Aksi Kegiatan Pengendalian Penyakit Tidak Menular. Ditjen Pencegah Penyakit dan Penyehatan Lingkungan, Kementeri Kesehat RI. 2017;43.

3. Usman Y, Iriawan RW, Rosita T, Lusiana M, Kosen S, Kelly M, et al. Indonesia's sample registration system in 2018: A work in progress. J Popul Soc Stud. 2018;27(1):39-52.

4. Kementerian Kesehatan RI. Pedoman Umum Pos Pembinaan Terpadu Penyakit Tidak Menular. Edisi satu cetakan ke dua. Ditjen Pengendalian Penyakit Tidak Menular. Kementerian Kesehatan Rl;2014;

5. Kemenkes RI. Profil Kesehatan Indonesia Tahun 2019. Kementeri Kesehat RI. 2020;42(4):1.

6. Kemenkes Rl. Petunjuk Teknis Pos Pembinaan Terpadu Penyakit Tidak Menular (Posbindu PTM). Ditjen Pengendali Penyakit dan Penyehatan Lingkungan, Kementeri Kesehat RI. 2012;1-39.

7. Puskesmas Beringin Raya. Data Pelaksanaan Posbindu Puskesmas Beringin Raya 2020. Bengkulu.

8. Anita B, Febriawati H, Yandrizal Y. The Role of Public Health Centers (Puskesmas) as the Gatekeeper of National Health Insurance. J Kesehat Masy. 2016;12(1):76-89.

9. Annisa N. Analisis Pelaksanaan Pos Pembinaan Terpadu Penyakit Menular di Wilayah Kerja Puskesmas Polonia Kecamatan Medan Polonia tahun 2016. J Kesehat Masyarakat Jur Ilmu Kesehat Masy Univ Sumatera Utara Medan. 2016;1(2):6-38.

10. Suhbah. WD Alviana, Suryawati. Chriswardani KW. Evaluasi Pelaksanaan Program Pos Pembinaan Terpadu Penyakit Tidak Menular (Posbindu Ptm) Puskesmas Sukolilo I Kabupaten Pati. J Kesehat Masyarakat FKM UNDIP. 2019;7(4):647-57.

11. Nugraheni WP, Hartono RK, Humaniora $P$, Kesehatan M, Penelitian B, Kesehatan P, et al. Strategi Penguatan Program Posbindu Penyakit Tidak Menular Di Kota Bogor Strengthening Strategies of Posbindu Program for Noncommunicable Diseases in Bogor City. J Ilmu Kesehat Masy. 2018;9(3):198-206.

12. Yanti. Nurul Evi, Lubis. Namora Lumongga DVE. Analisis Implementasi Kebijakan Puskesmas Dalam Program Pos Pembinaan Terpadu Penyakit Tidak Menular. The Indonesian Journal of Health Promotion. 2019;2(3):174-180.

13. Putri RE, Hubayah H, Asparian A. Evaluasi Proses Implementasi Posbindu PTM Di Wilayah Kerja Puskesmas Simpang Sungai Duren Kecamatan Jambi Luar Kota Kabupaten Muaro Jambi Tahun. J Kesmas Jambi. 2018;2(1):12-27.

14. Alfiyah A, Pujiyanto P. an Analysis on the Implementation of the Integrated Guidance 
Post (Posbindu) Activities for Non-Communicable Diseases At Bogor City in 2018. J Indones Heal Policy Adm. 2019;4(1):11-5.

15. Pranandari. LA, Arso. SP FE. Analisis Implementasi Program Pos Pembinaan Terpadu Penyakit Tidak Menular (Posbindu Ptm) Di Kecamatan Banguntapan Kabupaten Bantul. $J$ Kesehat Masy. 2017;5(4):76-84.

16. Febriawati. H, Angraini. W, Lina. LF, Oktarianita, Pratiwi. BA, Safarudin, Suryani. D Y. Analisis of Indonesian Health Program throught Family Aproach (PIS-PK) in the Working Area of Public Health Center of Jalan Gedang. Pakistan J Med Helth Sci Pakistan. 2020;14(1):581-585.

17. Febriawati $\mathrm{H}$, Alfansi L, Hadi ED, Ab SA. The role of management function to the achievement of Puskesmas indicator as a gatekeeper of national health guarantee in Bengkulu City. Indian J Public Heal Res Dev. 2018;9(9):353-7.

18. Irmawati. Refiola, Wigati. PA AS. Analisis Pelaksanaan Program POS Pembinaan Terpadu Pnyakit Tidak Menular Di Wilayah Kerja Puskemas Srondol Kulon, Kota Semarang (Studi Kasus Di Rw 13, Kecamatan Srondol Wetan, Kelurahan Banyumanik). $J$ Kesehat Masy. 2018;6(1):57-70.

19. Kiting RP, Ilmi B, Arifin S. Faktor Yang Berhubungan Dengan Kinerja Kader Posbindu Penyakit Tidak Menular. J Berk Kesehat. 2017;1(2):106.

20. Maryaningsih. Hubungan persepsi dan kebutuhan masyarakat terhadap pemanfaatan pos pembinaan terpadu Di puskesmas helvetia medan. Gentle Birth Journal. 2020;3(1):30-37. 